\title{
King syndrome: what's in a name?
}

\author{
Laurie M. Connors \\ Vanderbilt University School of Nursing, Vanderbilt University, Nashville, TN 37240, USA \\ Correspondence to: Dr. Laurie M. Connors, Vanderbilt University School of Nursing, Vanderbilt University, 461 21st Ave South, \\ Nashville, TN 37240, USA. E-mail: laurie.m.connors@vanderbilt.edu \\ How to cite this article: Connors LM. King syndrome: what's in a name? J Transl Genet Genom 2021;5:130-2. \\ https://dx.doi.org/10.20517/jtgg.2021.17
}

Received: 18 Mar 2020 Accepted: 18 Mar 2021 Available online: 26 Mar 2021

Academic Editor: Sanjay Gupta Copy Editor: Yue-Yue Zhang Production Editor: Yue-Yue Zhang

Hereditary breast and ovarian cancers have been associated with pathogenic genetic variants in the BRCA1 and $B R C A 2$ genes for nearly 30 years due to the arduous work of Dr. Mary Claire King. Dr. King and her research team identified the location of the $B R C A 1$ gene in $1990^{[1]}$. Unfortunately, patent protection enlisted by a biotechnology company limited access to BRCA genetic testing and research for nearly 20 years. In June 2013, after the U.S. Supreme Court unanimously ruled that isolated human genes cannot be patented, access and research on $B R C A 1 / 2$ genes greatly expanded.

Yet, a gender bias likely exists which limits access to $B R C A$ testing for males by a syndromic name that only associates $B R C A$ pathogenic variants with breast and ovarian cancers. It is estimated that 1 in 400 individuals harbor a germline $B R C A 1$ or $B R C A 2$ mutation and that estimate increased to 1 in 40 individuals of Ashkenazi Jewish ancestry ${ }^{[2]}$. There are disparities which exist for access to $B R C A$ genetic testing with regard to education level, insurance status, and race/ethnicity ${ }^{[3]}$. Gender is an additional disparity as men and women equally harbor these mutations, yet there is a significant difference in testing with women tested significantly more often than men ${ }^{[4]}$. If the syndrome associated with mutations in BRCA1/2 was changed to King syndrome, the myopic view would not just be on breast and ovarian cancers, which have a preponderance for the female population. 


\section{BRCA AND MALE SPECIFIC CANCER}

Prostate cancer is one of the most common cancers in men and those impacted with aggressive or metastatic disease should complete genetic testing with next generation sequencing of the BRCA genes. For the past years, the National Comprehensive Cancer Network (NCCN) guidelines ${ }^{[5]}$ for hereditary breast and ovarian cancesr have included the consideration of $B R C A 1$ and $B R C A 2$ genetic testing for men who meet certain criteria, including a prostate cancer diagnosis with Gleason score of $\geq 7$ or metastatic prostate cancer (NCCN, Genetic/Familial High-Risk Assessment Breast and Ovarian 2019a). Pritchard et al. ${ }^{[6]}$ identified the importance of germline genetic testing in men with metastatic prostate cancer, $B R C A 2$ representing the most identified pathogenic variant.

There is clinical utility in establishing the presence of mutations in DNA repair genes, such as BRCA, to define cancer subtypes that have distinct vulnerabilities to specific therapeutic such as Poly [adenosine diphosphate (ADP)-ribose] polymerase (PARP) inhibitors ${ }^{[7]}$. Poly (ADP-ribose) polymerase is a cellular mechanism for repairing single-strand DNA breaks. If $B R C A$ is mutated, PARP must repair both types of DNA breaks, and cells depend on the PARP repair mechanism. Therefore, use of the PARP inhibitors class of medications in individuals with $B R C A 1$ and $B R C A 2$ mutations should result in cancer cell death through a type of directed synthetic lethality ${ }^{[8]}$. Poly (ADP-ribose) polymerase inhibitors are a consideration for the treatment of ovarian and breast cancers with germline BRCA1 and BRCA2 mutations and have activity in castration-resistant prostate cancer with germline or somatic mutations in certain DNA repair genes, such as $B R C A 1$, and $B R C A 2^{[7]}$.

\section{HAVE BEEN HERE BEFORE}

There has been a similar circumstance in cancer genetics with the re-naming of hereditary non-polyposis colorectal cancer to Lynch syndrome $e^{[9]}$. Lynch syndrome is a hereditary cancer syndrome associated with an increased lifetime risk of developing colorectal cancer as well as stomach cancer, ovarian cancer, hepatobiliary tract cancer, urinary tract cancer, and cancers of small bowel, brain, and skin. Lynch syndrome is associated with pathogenic genetic variants in multiple different genes, including $M L H 1$, MSH2, MSH6, and PMS2, which are considered to mismatch repair genes and have therapeutic implications specific to immunotherapy ${ }^{[10]}$. Previous research demonstrated the benefit of testing tumors and patients for Lynch syndrome as the questionable benefit of standard systemic chemotherapy regimens based on cisplatin and 5-fluorouracil in the setting of mutations in mismatch repair genes ${ }^{[11-14]}$. Lynch Syndrome provides an early adoption of molecular analysis of solid tumor patients to guide individual oncology treatment and by removing the colorectal cancer focus to the syndrome, a wider net became available to capture cancers associated with mutations in the mismatch repair genes.

It is timely and necessary to rename hereditary breast and ovarian cancer syndrome to King syndrome, to assume a wider assessment of cancer that has occurred, or may occur, and due pathogenic variants in $B R C A 1$ or BRCA2. Genetic testing and molecular analysis for oncology patients of all genders (female, male, and trans) and cancer types (breast, ovarian, pancreas, and prostate) is necessary if the true benefit of personalized medicine is to be gained for the entire population. King syndrome would raise awareness and expand health care provider consideration of genetic testing for cancers other than only breast and ovarian. By a simple name change, King syndrome provides a broader scope to impact health outcomes and save lives.

\section{DECLARATIONS}

\section{Authors' contributions}

The author contributed solely to the article. 


\section{Availability of data and materials}

Not applicable.

\section{Financial support and sponsorship}

None.

\section{Conflicts of interest}

The author declared that there are no conflicts of interest.

\section{Ethical approval and consent to participate}

Not applicable.

\section{Consent for publication}

Not applicable.

\section{Copyright}

(c) The Author(s) 2021.

\section{REFERENCES}

1. King MC. "The race" to clone BRCA1. Science 2014;343:1462-5. DOI PubMed

2. Petrucelli N, Daly M, Feldman G. Hereditary breast and ovarian cancer due to mutations in BRCA1 and BRCA2. Genet Med 2010;12:245-59. DOI PubMed

3. Suther S, Kiros GE. Barriers to the use of genetic testing: a study of racial and ethnic disparities. Genet Med 2009;11:655-62. DOI PubMed

4. Childers KK, Maggard-Gibbons M, Macinko J, Childers CP. National Distribution of Cancer Genetic Testing in the United States: Evidence for a Gender Disparity in Hereditary Breast and Ovarian Cancer. JAMA Oncol 2018;4:876-9. DOI PubMed PMC

5. National Comprehensive Cancer Network Guidelines (2020). Genetic/Familial High-Risk Assessment Breast and Ovarian, Retrieved from https://www.nccn.org/professionals/physician_gls/pdf/genetics_screening.pdf [Last accessed on 23 Mar 2021].

6. Pritchard CC, Mateo J, Walsh MF, et al. Inherited DNA-Repair Gene Mutations in Men with Metastatic Prostate Cancer. $N$ Engl J Med 2016;375:443-53. DOI PubMed PMC

7. Mateo J, Carreira S, Sandhu S, et al. DNA-Repair Defects and Olaparib in Metastatic Prostate Cancer. N Engl J Med 2015;373:1697708. DOI PubMed PMC

8. Lord CJ, Ashworth A. PARP inhibitors: Synthetic lethality in the clinic. Science 2017;355:1152-8. DOI PubMed PMC

9. CR, Lynch, HT. The history of Lynch syndrome. FAM CANCER 2013;12:145-57.

10. Zhao P, Li L, Jiang X, Li Q. Mismatch repair deficiency/microsatellite instability-high as a predictor for anti-PD-1/PD-L1 immunotherapy efficacy. J Hematol Oncol 2019;12:54. DOI PubMed PMC

11. Aebi S, Kurdi-Haidar B, Gordon R, et al. Loss of DNA mismatch repair in acquired resistance to cisplatin. Cancer Res 1996;56:308790. PubMed

12. Arnold CN, Goel A, Boland CR. Role of hMLH1 promoter hypermethylation in drug resistance to 5-fluorouracil in colorectal cancer cell lines. Int J Cancer 2003;106:66-73. DOI PubMed

13. Carethers JM, Chauhan DP, Fink D, et al. Mismatch repair proficiency and in vitro response to 5-fluorouracil. Gastroenterology 1999;117:123-31. DOI PubMed PMC

14. Fink D, Nebel S, Aebi S, et al. The role of DNA mismatch repair in platinum drug resistance. Cancer Res 1996;56:4881-6. PubMed 